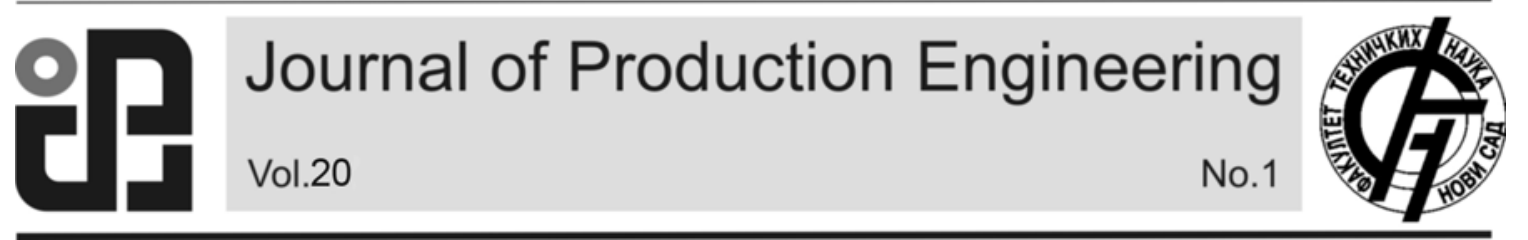

JPE (2017) Vol.20 (1)

Nageswara, R.M., Narayana, R.K.., Ranga, J.G.

Original Scientific Paper

\title{
INTEGRATED SCHEDULING OF MACHINES AND AGVS IN FMS BY USING DISPATCHING RULES
}

Received: 17 April 2017 / Accepted: 20 May 2017

\begin{abstract}
Recent advancement in meta-heuristics for simultaneous scheduling of machines and AGV studies have applied various techniques such as Differential evaluation (DE), Simulated Annealing (SA) and Ant Colony Optimization (ACO) to solve the simultaneous scheduling problem. All of these technique requires an initial scheduler in order to initiate the scheduling process and the priority rule algorithms will typically be used. However, from the literature, none of these studies elaborate and justify their selection of a particular priority rule algorithms over another. Since the initial scheduler can significantly affect the entire scheduling process, it is important that the correct initial scheduler be selected. In this paper we quantitatively compared three initial scheduler algorithms to determine the best algorithm performance. We believe the performance comparison would enable users to utilize the best initial scheduler to fit their meta-heuristics simultaneous scheduling studies.
\end{abstract}

Key words: simultaneous scheduling, priority rules, performance

Integrisano raspoređivanje mašina i AGVs u FMS korištenjem dispečerska pravila. Nedavni napredak u metaheuristici za istovremeno raspoređivanje mašina $i$ AGV studije su primenjeni u raznim tehnikama, kao što je diferencijalno vrednovanje (DE), Simulano žarenje (SA) i Optimizacija uz pomoć kolonije mrava (ACO) da reši istovremeno raspoređivanje problem. Sve ove tehnike zahtevaju inicijalni planer kako bi se započeo proces za raspoređivanje i algoritmi prioriteta pravila koja će se obično koristiti. Međutim, iz literature, nijedna od ovih studija ne elaborira i opravdava izbor određenog prioriteta pravila algoritama nad drugim. Pošto početni raspored može značajno uticati na čitav proces za raspoređivanje, važno je da se izabere ispravn početni planer. U ovom radu su kvantitativno upoređena tri početna planer algoritma da bi se odredile najbolje performanse algoritma. Veruje se da će poređenje performansi omogućiti korisnicima da postave najbolji početni planer da bi odgovarao njihovoj meta heuristikoj simultanoj studiji raspoređivanja.

Ključne reči: simultano raspoređivanje, prioritetna pravila, performanse

\section{INTRODUCTION}

FMS is a highly automated and sophisticated system in the field of manufacturing to achieve high flexibility and productivity in mid-variety and midrange of products $[1,2]$. The great demand for goods needs new way to enhance productivity with existing manufacturing system and available resources. FMS has emerged as a viable alternative to the conventional manufacturing system and showed benefits in cost reduction, enhanced utilizations, reduced work-inprocess levels, etc. The problems encountered in the life cycle of a FMS are classified in to design, planning, scheduling and control [3]. The task of scheduling and controling problems plays an important role during operation owing to the dynamic nature of the FMS such as flexible parts, tools, AGV routings [4] and AS/RS storage assignments[5].scheduling of machines in FMS is made through sequencing of jobs on machines, and routing of jobs through the system [6,7]. Other resources in the system,(e.g. material-handling devices like AGVs and AS/RS) need to be considered. To have flexible and efficient production, automated guided vehicle systems (AGVS) and the material-handling system (MHS) are being employed [8,9]. The AGVs effectiveness depends on several factors. Function of a well-designed vehicle management are: Dispatching the process of selecting and assigning tasks to $\mathrm{AGV}$; Routing the process of selecting specific paths by AGVs; and Scheduling - the process of determining the arrival and departure dates. The demand for goods enhances pressure on manufacturing systems seeking ways to increase productivity with available resources. Scheduling is a critical function for the control and operation of any FMS [10].

\subsection{Dispatching rules}

Over the last four decades, the sequencing and scheduling problem has been solved using dispatching rules (also called scheduling rules, sequencing rules, decision rules, or priority rules). These dispatching rules are used to determine the priority of each job. The priority of a job is determined as a function of job parameters, machine parameters, or shop characteristics. When the priority of each job is determined, jobs are sorted and then the job with the highest priority is selected to be processed first. Baker [11] and Morton and Pentico [12] classified dispatching rules as follows:

\section{Local rules}

Local rules are concerned with the local available information.

Global rules

Global rules are used to dispatch jobs using all 
information available on the shop floor.

\section{Static rules}

Static rules do not change over time, and ignore the status of the job shop floor.

\section{Dynamic rules}

Dynamic rules are time dependent, and change according to the status of the job shop floor.

\section{Forecast rules}

Forecast rules are used to give priority to jobs according to what the job is going to come across in the future, and according to the situation at the local machine. Several dispatching rules have been reported by many researchers. The following are some of the dispatching rules that have been developed, investigated, and implemented by several researchers and practitioners:

1. SPT or SEPT: Shortest Processing Time or Shortest Expected Processing Time. The job with the smallest operation processing time is processed first.

2. LPT or LEPT: Longest Processing Time or Longest Expected Processing Time. The job with the largest operation processing time is processed first.

3. EDD: Earliest Due Date. The job with the smallest due date is processed first.

4. JST: Job Slack Time. The job with minimum slack is processed first. The job slack time is computed as the difference between the job due date, the work remaining, and the current time.

5. CR: Critical Ratio. The job with the smallest ratio is processed first. The CR is determined by dividing job's allowance by the remaining work time.

6. RANDOM: Service in Random Order. A job is randomly selected from the set of jobs which are queued at the machine.

7. FCFS or SORT: First Come, First Served or Smallest Ready Time. The job which arrives first at the machine will be served first.

8. LCFS: Last Come, First Served. The job which arrives last will be served first.

9. LFJ: Least Flexible Job. The job with the least flexibility is processed first.

10. FOFO: First Off, First On. The job with the operation that could be completed earliest will be processed first even if this operation is not yet in the queue. In this case, the machine will be idle until the operation arrives.

11. LAWINQ: Least Anticipated Work in Next Queue. From the set of jobs waiting for a specific machine, a job will be selected that will encounter the smallest queue at the next machine in its route.

12. COVERT: Cost OVER Time. COVERT is a composite rule that puts the job with the largest COVERT ratio in first position. The COVERT ratio is computed by dividing an anticipated tardiness for the associated job and its operation processing time.

13. Most Operation Remaining Rule (MOPNR): Every job has a number of operations and according to this rule the operation which has more number of succeeding operations will be given the first priority.

14. Preferred Customer Order (PCO): Sometimes jobs belonging to a particular customer may be given priority for different reasons like the business offered by them is more than that offered by others or because of their regular business orders etc.

15. Least Slack (LS): Generally there is always a difference between actual finishing time of the job and the due date by which it is supposed to be finished, which is known as "slack". According to this rule the job with the least slack is given first priority as mentioned earlier.

\section{SCHEDULING WITH DISPATCHING RULES}

Scheduling provides a basis for assigning jobs, whereas sequencing (also referred as dispatching) specifies the priority for completion of jobs in a systematic way at WorkCentre.Hanssmann and Hess [13] have adopted the Linear Programming (LP) in a model to achieve maximum profit or lowest cost. Held and Karp [14] have applied the dynamic programming (DP) while solving a large problem. Ignall and Schrage [15] have developed branch and bound algorithms for the permutation flow shop problem with makespan minimization. Bomberger [16] has followed the DP approach considering the production scheduling of different items over the same facility in the system on a repetitive basis. The facility in the system is: only one item can be produced at a time associating with setup cost and setup time under constant demand rate. Campbell et al. [17] have applied heuristic algorithm in stages. Lockett and Muhlemann [18] have used the branch and bound algorithm for scheduling jobs with sequencing suitable for small size problems. Crowin and Esogbue [19] have considered two different flow shop scheduling problems for minimizing makespan. After establishing the optimum permutation schedules, an efficient DP formulation has been developed. Holland [20] has invented the algorithms based on Darwin's theory of natural selection and survival. These were invented by. Rinnooy Kan [21] has formulated mathematical programming models and obtained unsatisfactory results. Majority of these techniques are unable to provide feasible solutions and have limited practical use. Panwalkar and Iskander [22] have utilized have classified 100 scheduling rules into static and dynamic rules. Tripathy [23] and, Arani et al. [24] have shown better results applying the integer programming on vehicle scheduling problem. Holthaus and Rajendran [25] have utilized the dispatching rules to optimize the job-shop scheduling problems in the manufacturing world. Pan and Fan [26]have used branch and bound algorithm for the problem and reduced the size of the problem including dominance properties. However, the algorithm is limited to 18 jobs. Chen et al. [27] have applied DP approach to Lagrangean relaxation for complex scheduling problems and found optimal solution for single and parallel machine problem. Papakostas and Chryssolouris [28] have proposed a dispatching rule (viz., RTSLACK) by maximizing the slack time of the remaining tasks in the manufacturing resources in a series of single machines and hybrid flow shop scheduling instances. Barman and Lisboa [29] have utilized a combination of dispatching rules for cost performance and minimized both mean and variable 
waiting cost. Ko et al. [30] have proposed a dispatching rule for non-identical parallel machines with sequence dependent setups and quality restrictions. Kayvanfar et al. [31] have examined a single machine scheduling problem with controllable processing times. Ying et al. [32] have studied the single-machine scheduling problem with a Common Due Window (CDW) having constant size and position to minimize the total weighted earliness and tardiness penalties in jobs completion. Ling et al. [33] minimizing total deviation of job completion time on a single machine scheduling. Dispatching rules have a significant role due to ease of implementation and compatibility with the dynamic

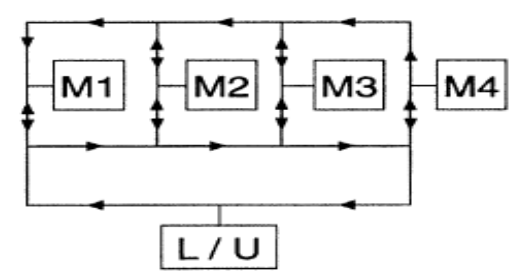

LAYOUT 1 nature of manufacturing systems.

\section{FMS DESCRIPTION}

The FMS considered in this work has the configurations as shown in Fig 1. There are four Machines having Computer Numerical Controlled Machines (CNCs) each equipped with an independent and self sufficient tool magazine, one Automatic Tool Changer (ATC) and one Automatic Pallet Changer (APC).

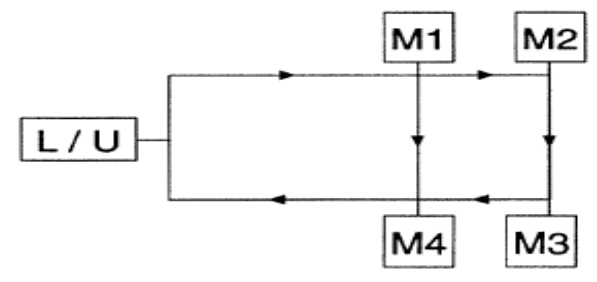

LAYOUT 2

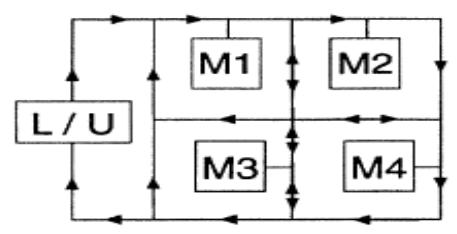

LAYOUT 4

LAYOUT 3

Fig. 1. the layout configurations adopted in example problems

\subsection{FMS Envirnoment}

The environment within which the FMS under consideration operates can be described as follows:

1. The types and number of machines are known. Operations are no preemptive. There is sufficient input/output buffer space at each machine

2. Processing, set-up, loading and unloading times are available and are deterministic.

3. Number of AGVs is given and the AGVs are all identical in the sense that they have the same speed and load carrying characteristics.

4. Flow path layout is given and travel times on each segment of the path are known.

5. A load/unload (L/U) station serves as a distribution center for parts not yet processed and as a collection center for parts finished. All vehicles start from the $\mathrm{L} / \mathrm{U}$ station initially and return to after accomplishing all their assignments. There is sufficient input/output buffer space at the $(\mathrm{L} / \mathrm{U})$ station.

6. AGVs carry a single unit-load at a time. They move along predetermined shortest paths, with the assumption of no delay due to congestion. Preemption of trips is not allowed. The trips are called loaded or deadheading (empty) trips depending on whether a part is carried or no part is carried during that trip, respectively. The durations for the deadheading trips are sequence dependent and are not known until the vehicle route is specified.

7. It is assumed that all the design and set-up issues within the hierarchy of OR/MS problems in an FMS as suggested by Stecke [34] have already been resolved. Machine loading, i.e., the allocation of tools to machines and the assignment of operations to machines, is made. Pallets and other necessary equipment are allocated to parts. The set of part types to be produced during the planning period and the routing of each part type are available before making scheduling decisions. In other words, routing flexibility is not considered. The routing for a part type can be selected based on considerations of technological feasibility and processing efficiency, or by formulating the set-up phase problems in a manner that can also handle the routing decisions.

8. Ready-times of all jobs are known. Initially, partially processed parts might be available at machines waiting for further processing, and they can be treated as jobs having zero ready times and their routing consists of the remaining operations.

9. Such issues as traffic control, congestion, machine failure or downtime, scraps, rework, and vehicle dispatches for battery change are ignored here and 
left as issues to be considered during real-time control.

\subsection{Assumptions}

a. The types and no. of machines are known

b. There is sufficient input/output buffer space for each machine

Machine loading

i. Allocation of tools to machine has been done

ii. Assignment of operation to machine are made

c. Pallet and other necessary equipment are allocated

d. The speed of AGV kept at $40 \mathrm{~m} / \mathrm{min}$

e. The distance between the two machines and distance between loading/ unloading machines are known

\subsection{Input data}

The input data i.e. travelling time matrix from table 1.1 and Job sets for the problem is taken from a paper by Bilge U and Ulusoy G [35]. Data given in Table 1. gives the distances from load/unload stations to machines and distances between machines in metres for all the four layouts.The Ten job sets are given in Table 2. given below each containing four to eight different job sets, machines in each job set to be used and numbers with in the parenthesis is the processing time of particular job on specified machine. The load/unload $(\mathrm{L} / \mathrm{U})$ station serves as a distribution center for parts not yet processed and as a collection center for parts finished. All vehicles start from the $\mathrm{L} / \mathrm{U}$ station initially. Trips follow the shortest path between two points either between two machines or between a machine and the L/U station. Preemption of trips is not allowed the trips are called loaded or deadheading (empty) trips. The durations for the deadheading trips are sequence dependent and are not known until the vehicle route is specified.

\begin{tabular}{|c|c|c|c|c|c|}
\hline Layout-1 & $\mathrm{L} / \mathrm{U}$ & M1 & M2 & M3 & M4 \\
\hline $\mathrm{L} / \mathrm{U}$ & 0 & 6 & 8 & 10 & 12 \\
\hline M1 & 12 & 0 & 6 & 8 & 10 \\
\hline M2 & 10 & 6 & 0 & 6 & 8 \\
\hline M3 & 8 & 8 & 6 & 0 & 6 \\
\hline M4 & 6 & 10 & 8 & 6 & 0 \\
\hline Layout-2 & $\mathrm{L} / \mathrm{U}$ & M1 & M2 & M3 & M4 \\
\hline $\mathrm{L} / \mathrm{U}$ & 0 & 4 & 6 & 8 & 6 \\
\hline M1 & 6 & 0 & 2 & 4 & 2 \\
\hline M2 & 8 & 12 & 0 & 2 & 4 \\
\hline M3 & 6 & 10 & 12 & 0 & 2 \\
\hline M4 & 4 & 8 & 10 & 12 & 0 \\
\hline Layout-3 & $\mathrm{L} / \mathrm{U}$ & M1 & M2 & M3 & M4 \\
\hline $\mathrm{L} / \mathrm{U}$ & 0 & 2 & 4 & 10 & 12 \\
\hline M1 & 12 & 0 & 2 & 8 & 10 \\
\hline M2 & 10 & 12 & 0 & 6 & 8 \\
\hline M3 & 4 & 6 & 8 & 0 & 2 \\
\hline M4 & 2 & 4 & 6 & 12 & 0 \\
\hline Layout-4 & $\mathrm{L} / \mathrm{U}$ & M1 & M2 & M3 & M4 \\
\hline $\mathrm{L} / \mathrm{U}$ & 0 & 4 & 8 & 10 & 14 \\
\hline M1 & 18 & 0 & 4 & 6 & 10 \\
\hline M2 & 20 & 14 & 0 & 8 & 6 \\
\hline M3 & 12 & 8 & 6 & 0 & 6 \\
\hline M4 & 14 & 14 & 12 & 6 & 0 \\
\hline
\end{tabular}

Table 1. Travel time matrix for this particular problem

\begin{tabular}{|l|l|}
\hline JobSet-1 & JobSet-2 \\
Job 1: Ml(8); M2(16); M4(12) & Job 1: Ml(10); M4(18) \\
Job 2: Ml(20); M3(10); M2(18) & Job 2: M2(10); M4(18) \\
Job 3: M3(12); M4(8); Ml(15) & Job 3: Ml(10); M3(20); \\
Job 4: M4(14); M2(18) & Job 4: M2(10); M3(15); M4(12) \\
Job 5: M3(10); Ml(15) & Job 5: Ml(10); M2(15); M4(12) \\
& Job 6: Ml(10); M2(15); M3(12) \\
\hline JobSet-3 & JobSet-4 \\
Job 1:Ml(16); M3(15) & Job1: M4(11); Ml(10); M2(7) \\
Job 2:M2(18); M4(15) & Job2: M3(12); M2(10); M4(8) \\
Job 3:Ml(20); M2(10) & Job3: M2(7); M3(10); Ml(9); M3(8) \\
Job 4:M3(15); M4(10) & Job4: M2(7); M4(8); Ml(12);M2(6) \\
Job 5:Ml(8);M2(10);M3(15);M4(17) & Job5:Ml(9);M2(7);M4(8);M2(10);M3(8) \\
Job 6: M2(10);M3(15);M4(8);Ml(15 & \\
\hline
\end{tabular}




\begin{tabular}{|l|l|}
\hline JobSet-5 & JobSet-6 \\
Job 1: Ml(6);M2(12);M4(9) & Job 1: Ml(9); M2(11); M4(7) \\
Job 2: Ml(18);M3(6); M2(15) & Job 2: Ml(19); M2(20); M4(13) \\
Job 3: M3(9);M4(3);Ml(12) & Job 3: M2(14); M3(20); M4(9) \\
Job 4: M4(6);M2(15) & Job 4: M2(14); M3(20); M4(9) \\
Job 5: M3(3);Ml(9) & Job 5: Ml(11); M3(16); M4(8) \\
& Job 6: Ml(10); M3(12); M4(10) \\
& \\
\hline JobSet-7 & JobSet-8 \\
Job 1: Ml(6); M4(6) & Job 1: M2(12); M3(21);M4(11) \\
Job 2: M2(11); M4(9) & Job 2: M2(12); M3(21);M4(11) \\
Job 3: M2(9); M4(7) & Job 3: M2(12); M3(21);M4(11) \\
Job 4: M3(16); M4(7) & Job 4: M2(12); M3(21);M4(11) \\
Job 5: Ml(9); M3(18) & Job 5: Ml(10); M2(14);M3(18);M4(9) \\
Job 6: M2(13); M3(19); M4(6) & Job 6: Ml(10);M2(14); M3(18);M4(9) \\
Job 7: Ml(10); M2(9); M3(13) & \\
Job 8: Ml(11); M2(9); M4(8) & \\
\hline JobSet-9 & JobSet-10 \\
Job 1: M3(9);Ml(12);M2(9);M4(6) & Job1:Ml(11);M3(19);M2(16);M4(13) \\
Job 2: M3(16);M2(11); M4(9) & Job2: M2(21);M3(16); M4(14) \\
Job 3: Ml(21); M2(18); M4(7) & Job3:M3(8); M2(10); Ml(14); M4(9) \\
Job 4: M2(20); M3(22); M4(11) & Job4: M2(13); M3(20); M4(10) \\
Job 5:M3(14);Ml(16);M2(13); M4(9) & Job5: Ml(9); M3(16); M4(18); \\
& Job6:M2(19);Ml(21); M3(11);M4(15) \\
\hline
\end{tabular}

Table 2. Data for the Job Sets Used in Example Problems

\subsection{Objective function}

Operation completion time $=\mathrm{Oij}=\mathrm{Tij}+\mathrm{Pij}$

$\mathrm{T}_{\mathrm{ij}}=$ Traveling time for $\mathrm{j}^{\text {th }}$ operation and $\mathrm{i}^{\text {th }}$ job

$\mathrm{P}_{\mathrm{ij}}=$ operation processing time

Mean Tardiness $=\frac{1}{n} \sum_{i=1}^{n} T_{i} \mathrm{n}=$ number of jobs;

$\mathrm{Ti}=$ Tardiness

Optimization parameters considered

Population Size $=$ Double the no of operations Iterations completed $=1000$

\subsection{Vehicle scheduling methodology}

Jobs are scheduled based on the operation sequence derived by the Sheep Flock Heredity algorithm. Initially AGVs carry jobs from the load/unload station to the respective workstations where the first operations are scheduled. AGVs make two types of trips, a loaded trip where it carries a load and a deadheading trip where the vehicle moves to pick up a load. Deadheading trip can start immediately after the delivery and vehicle demand at different workstations are considered and the subsequent assignments are made. If both AGVs are available task is assigned to the earliest available vehicle. If no vehicle is available, the earliest available times of the AGVs are computed and the assignment is made. If the vehicle is idle and no job is ready, assign the operation that is going to be completed early and is identified the vehicle is moved to pick up that job. This type of vehicle scheduling methodology helps in reducing the waiting times and thus helps in improving the resource utilization and the throughput. The flow chart of the vehicle assignment methodology is given in Fig. 2.

\section{IMPLEMENTATION OF SEQUENCING RULES}

Scheduling provides a basis for assigning jobs to a work center. Sequencing (also referred to as dispatching) specifies the order in which jobs should be completed at each centre. The sequencing methods are referred to as priority rules for sequencing or dispatching jobs to a work center. In the manufacturing world, scheduling problems are extensively adopting the dispatching rules to provide good solutions to complex problems in a real-time production environment.

\subsection{First cum First Serve(FCFS)}

For implementation of First cum first serve rule, Job set 5 and Layout1 is considered.

$$
\text { Job Set } 5
$$

Job1 Job2 Job3 Job4 Job5 $\begin{array}{llllllllllllll}M_{1} & M_{2} & M_{4} & M_{1} & M_{3} & M_{2} M_{3} & M_{4} & M_{1} M_{4} & M_{2} & M_{3} & M_{1}\end{array}$

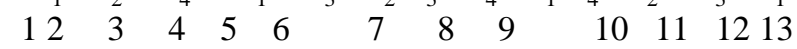

In FCFS continuous numbers are marked initially for the operations in a job set by following precedence relation, i.e., operation of the same job set must be in increasing order but anywhere in the sequence. According to this rule the sequence is.
12
45
$\begin{array}{llll}7 & 8 & 9 & 10\end{array}$
$11 \quad 12 \quad 13$

\subsection{Shortest processing time (SPT)}

For implementation of shortest processing time rule, Job set 3 and Layout 2 are considered.

In SPT continuous numbers are marked initially for the operations in a job set by following precedence relation. And the total process time for each and every job is found out. For example in the above Job set total 
processing times are job1-31, job2-33, job3-30, job425, job5-50, and job6-44. According to this rule the priority of job is 4, 3, 1, 2, 6, 5 and the sequence is:

$\begin{array}{lllllllllllll}8 & 5 & 6 & 12 & 3 & 4 & 14 & 15 & 16 & 9 & 10 & 11 & 12\end{array}$

Job set 3

\begin{tabular}{|c|c|c|c|c|c|c|c|c|c|c|c|c|c|c|c|}
\hline \multicolumn{2}{|c|}{ Job 1 } & \multicolumn{2}{|c|}{ Job 2 } & \multicolumn{2}{c|}{ Job 3 } & \multicolumn{3}{c|}{ Job 4 } & \multicolumn{4}{c|}{ Job 5} & \multicolumn{4}{c|}{ Job 6} \\
\hline M1 & M3 & M2 & M4 & M1 & M2 & M3 & M4 & M1 & M2 & M3 & M4 & M2 & M3 & M4 & M1 \\
\hline 16 & 15 & 18 & 15 & 20 & 10 & 15 & 10 & 8 & 10 & 15 & 17 & 10 & 15 & 8 & 15 \\
\hline 1 & 2 & 3 & 4 & 5 & 6 & 7 & 8 & 9 & 10 & 11 & 12 & 13 & 14 & 15 & 16 \\
\hline
\end{tabular}

\subsection{Longest processing time (LPT)}

For implementation of longest processing time rule, Job set 9 and Layout 3 are considered.

In LPT continuous numbers are marked initially for the operations in a job set by precedence relation. The total process time for each and every job is found. For example in job set No 9 total processing times are job1-
36, job2-36, job3-46, job4-53, and for job5-52, since both the process times are same first one is selected as priority. According to this rule the priority of job is 4, $5,3,1,2$ and the sequence is:

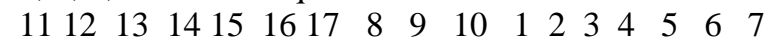

And the test results obtained by simulating FCFS, SPT and LPT for simultaneous scheduling problems are given below in Table 3. and Table 4.

Job set 9

\begin{tabular}{|c|c|c|c|c|c|c|c|c|c|c|c|c|c|c|c|c|}
\hline \multicolumn{4}{|c|}{ Job 1} & \multicolumn{3}{|c|}{ Job 2} & \multicolumn{3}{|c|}{ Job 3} & \multicolumn{3}{|c|}{ Job 4} & \multicolumn{4}{|c|}{ Job 5} \\
\hline M3 & M1 & M2 & M4 & M3 & M2 & M4 & M1 & M2 & M4 & M2 & M3 & M4 & M3 & M1 & M2 & M4 \\
\hline 9 & 12 & 9 & 6 & 16 & 11 & 9 & 21 & 18 & 7 & 20 & 22 & 11 & 14 & 16 & 13 & 19 \\
\hline 1 & 2 & 3 & 4 & 5 & 6 & 7 & 8 & 9 & 10 & 11 & 12 & 13 & 14 & 15 & 16 & 17 \\
\hline
\end{tabular}

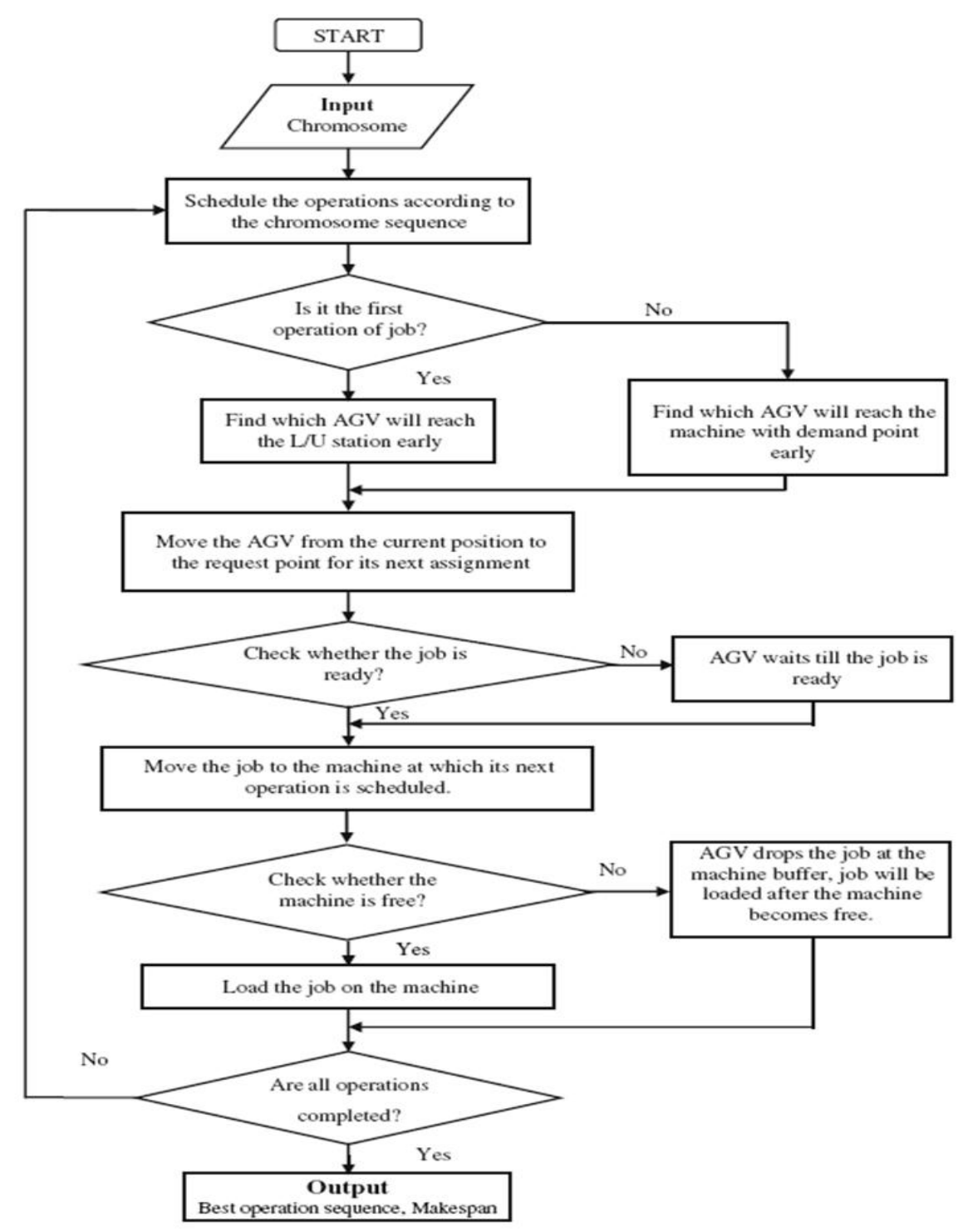

Fig. 2. flow chart for Simultaneous scheduling machines and AGVs 


\section{RESULT AND DISCUSSION}

Ten different job sets with different processing sequences, and process times are generated and presented. Different combinations of these ten job sets and four layouts are used to generate 82 example problems. In all these problems there are two vehicles. Table 3. consists of problems whose $t_{i} / p i$ ratios are greater than 0.25 , and whose $t_{i} / p i$ ratios are lesser than
0.25 ratios are represented in Table 4. A code is used to designate the example problems which are given in the first column. The digits that follow 1.1 indicate the job set and the layout. In Table 2 another digit is appended to the code. Here, having a 0 or 1 as the last digit implies that the process times are doubled or tripled, respectively, where in both cases travel times are halved.

\begin{tabular}{|c|c|c|c|c|}
\hline Job. No & $t / p$ & FCFS & SPT & LPT \\
\hline 1.1 & 0.59 & 173 & 193 & 177 \\
\hline 2.1 & 0.61 & 158 & 158 & 177 \\
\hline 3.1 & 0.59 & 202 & 224 & 198 \\
\hline 4.1 & 0.91 & 263 & 267 & 264 \\
\hline 5.1 & 0.85 & 148 & 164 & 148 \\
\hline 6.1 & 0.78 & 231 & 240 & 227 \\
\hline 7.1 & 0.78 & 195 & 210 & 201 \\
\hline 8.1 & 0.58 & 261 & 261 & 266 \\
\hline 9.1 & 0.61 & 270 & 277 & 268 \\
\hline 10.1 & 0.55 & 308 & 308 & 310 \\
\hline 1.2 & 0.47 & 143 & 173 & 165 \\
\hline 2.2 & 0.49 & 124 & 124 & 130 \\
\hline 3.2 & 0.47 & 162 & 188 & 160 \\
\hline 4.2 & 0.73 & 217 & 223 & 224 \\
\hline 5.2 & 0.68 & 118 & 144 & 131 \\
\hline 6.2 & 0.54 & 180 & 169 & 165 \\
\hline 7.2 & 0.62 & 149 & 160 & 149 \\
\hline 8.2 & 0.46 & 181 & 181 & 198 \\
\hline 9.2 & 0.49 & 250 & 249 & 244 \\
\hline 10.2 & 0.44 & 290 & 288 & 287 \\
\hline 1.3 & 0.52 & 145 & 175 & 167 \\
\hline 2.3 & 0.54 & 130 & 130 & 136 \\
\hline 3.3 & 0.51 & 160 & 190 & 162 \\
\hline 4.3 & 0.8 & 233 & 237 & 230 \\
\hline 5.3 & 0.74 & 120 & 146 & 133 \\
\hline 6.3 & 0.54 & 182 & 171 & 167 \\
\hline 7.3 & 0.68 & 155 & 166 & 151 \\
\hline 8.3 & 0.5 & 183 & 183 & 200 \\
\hline 9.3 & 0.53 & 252 & 251 & 246 \\
\hline 10.3 & 0.49 & 293 & 294 & 293 \\
\hline 1.4 & 0.74 & 189 & 207 & 189 \\
\hline 2.4 & 0.77 & 174 & 174 & 174 \\
\hline 3.4 & 0.74 & 220 & 250 & 212 \\
\hline 4.4 & 1.14 & 301 & 301 & 298 \\
\hline 5.4 & 1.06 & 171 & 189 & 171 \\
\hline 6.4 & 0.78 & 249 & 252 & 237 \\
\hline 7.4 & 0.97 & 217 & 242 & 151 \\
\hline 8.4 & 0.72 & 285 & 285 & 200 \\
\hline 9.4 & 0.76 & 292 & 311 & 290 \\
\hline 10.4 & 0.69 & 350 & 350 & 345 \\
\hline
\end{tabular}

Table 3. Performance evaluation for t/p $>0.25$ considering FCFS, SPT and LPT procedures 


\begin{tabular}{|c|c|c|c|c|}
\hline Job.No & $\mathrm{t} / \mathrm{p}$ & FCFS & SPT & LPT \\
\hline 1.10 & 0.15 & 207 & 248 & 252 \\
\hline 2.10 & 0.15 & 217 & 217 & 225 \\
\hline 3.10 & 0.15 & 257 & 327 & 282 \\
\hline 4.10 & 0.15 & 303 & 328 & 317 \\
\hline 5.10 & 0.21 & 152 & 190 & 187 \\
\hline 6.10 & 0.16 & 304 & 281 & 297 \\
\hline 7.10 & 0.19 & 231 & 240 & 264 \\
\hline 8.10 & 0.14 & 338 & 338 & 347 \\
\hline 9.10 & 0.15 & 390 & 367 & 359 \\
\hline 10.10 & 0.14 & 452 & 429 & 444 \\
\hline 1.20 & 0.12 & 194 & 238 & 246 \\
\hline 2.20 & 0.12 & 194 & 194 & 206 \\
\hline 3.20 & 0.12 & 241 & 311 & 270 \\
\hline 4.20 & 0.12 & 285 & 312 & 298 \\
\hline 5.20 & 0.17 & 142 & 180 & 184 \\
\hline 6.20 & 0.12 & 292 & 260 & 284 \\
\hline 7.20 & 0.15 & 212 & 218 & 249 \\
\hline 8.20 & 0.11 & 306 & 319 & 334 \\
\hline 9.20 & 0.12 & 380 & 355 & 347 \\
\hline 10.20 & 0.11 & 445 & 423 & 439 \\
\hline 1.30 & 0.13 & 195 & 239 & 247 \\
\hline 2.30 & 0.13 & 197 & 197 & 209 \\
\hline 3.30 & 0.13 & 240 & 312 & 271 \\
\hline 4.30 & 0.13 & 292 & 317 & 301 \\
\hline 5.30 & 0.18 & 141 & 181 & 183 \\
\hline 6.30 & 0.24 & 296 & 261 & 285 \\
\hline 7.30 & 0.17 & 215 & 221 & 250 \\
\hline 8.30 & 0.13 & 307 & 320 & 335 \\
\hline 9.30 & 0.13 & 381 & 356 & 348 \\
\hline 10.30 & 0.12 & 448 & 426 & 442 \\
\hline 1.40 & 0.18 & 213 & 255 & 254 \\
\hline 2.41 & 0.13 & 307 & 307 & 319 \\
\hline 3.40 & 0.18 & 261 & 330 & 282 \\
\hline 3.41 & 0.12 & 370 & 476 & 411 \\
\hline 4.41 & 0.19 & 434 & 471 & 451 \\
\hline 5.41 & 0.18 & 218 & 269 & 270 \\
\hline 6.40 & 0.19 & 310 & 288 & 299 \\
\hline 7.40 & 0.24 & 239 & 251 & 270 \\
\hline 7.41 & 0.16 & 329 & 344 & 385 \\
\hline 8.40 & 0.18 & 343 & 343 & 349 \\
\hline 9.40 & 0.19 & 396 & 379 & 370 \\
\hline 10.40 & 0.17 & 466 & 445 & 455 \\
\hline
\end{tabular}

Table 4. Performance evaluation for $\mathrm{t} / \mathrm{p}<0.25$ considering FCFS, SPT and LPT procedures

\section{CONCLUSIONS}

In this paper the optimal sequence of machines and AGVs are determined by using FCFS, SPT and LPT from Table no 3. and table 4 . it is observed that from table 3. out of 40 problems 22 problems gives better results using FCFS when compared with SPT and LPT,
8 problems gives better results using SPT when compared with FCFS and LPT and 24 problems gives better results using LPT when compared with SPT and FCFS and also it can be observed that from table 4. out of 42 problem 30 problems gives better results using FCFS when compared with SPT and LPT, 14 problems gives better results using SPT when compared with 
FCFS and LPT and 4 problems gives better results using LPT when compared with SPT and FCFS.

\section{REFERENCES}

[1] Akturk M.S., Yilmaz H.: Scheduling of automated guided vehicles in a decision making hierarchy, International Journal of Production Research, 32, 577-591 (1996)

[2] Sabuncuoglu. I, Hommertzheim D.L.: Experimental investigation of FMS machine and AGV scheduling rules against the mean flow time criterion. Inter: journal of production research, 30(7) 1617-1635 (1992).

[3] Karabtik.S. Sabuncuolu I.: A beam search based algorithm for scheduling machines and AGVs in an FMS. In: Proceedings of the Second Industrial Engineering Research Conf, Los Angeles, 308-312 (1993).

[4] Kusiaka. Material Handling in Flexible Manufacturing Systems. Material Flow, 2, 90-95 (1985).

[5] El-Maraghy.H.A., Ravi.T. Modern tools for the design, modelling and evaluation of flexible manufacturing systems, Int J Robot Comput Integr Manuf, 9(4), 335-340 (1992).

[6] Orhan.E., Alper.D. : A new approaches to solve hybrid flow shop scheduling problems by artificial immune system, Future Generation Computer Systems, 20 1083-1095 (2004)

[7] Lee S.M, Jung.H.J.: A multi-objective production planning model in a flexible manufacturing environment. Int J Prod Res, 27(11), 1981-1992 (1989)

[8] Raman. N., Talbot F.B., Rachamadgu. R..: Simultaneous scheduling of machines and material handling devices in automated manufacturing, In: Proc Second ORSA/TIMS Conf.on FMS (1986)

[9] Blazewicz. J., Eiselt. H.A, Finke. G., Laporte. G., Weglarz. J.: Scheduling tasks and vehicles in a flexible manufacturing system, Int J Flex Manuf Syst,4,5-16 (1991)

[10] Sabuncuogluand. I., Hommertzheim D.L.: Dynamic dispatching algorithm for scheduling machines and automated guided vehicles in a flexible manufacturing system,Int J Prod Res,30,1059-1079 (1992)

[11]Baker, K.R..: Introduction to Sequencing and Scheduling, Wiley, New York, (1974)

[12] Thomas Morton and David Pentico.: A Volume in the Wiley Series in Engineering and Technology Management, (Ed.) D.Kocaoglu, Chapter 13.2.2,(1993)

[13] Hanssmann. F., Hess.S. W.: A linear programming approach to production and Employed scheduling. Management Technology, 1, 46-54 (1960)

[14] Michael Held., Richard M.Karp.: A Dynamic Programming Approach to Sequencing Problems. Journal of the Society for Industrial and Applied Mathematics, 10 (1), 196-210 (192)

[15] Ignall, E., Schrage, L.: Applications of the branch and bound techniques to some flow shop scheduling problems Operations Research, 13,400-
412 (1965)

[16]Bomberger.E.E.: A Dynamic Programming Approach to A Lot Size Scheduling Problem, JSTOR: Management Science, USA, 12(11), 778784 (1966)

[17] Campbell, H.G., Dudek, R.A. and Smith, M.L.: A heuristic algorithm for the n-job m-machine sequencing problem. Management Science 16(10), 169-174(1970)

[18] Lockett, A.G. and Muhlemann, A.P.: Technical notes: a scheduling Problem involving sequence dependent changeover times. Operation Research 20, 895- 902(1972)

[19] Corwin, B. D. and Esogbue, A. O.: Two machine flow shop scheduling problems with sequence dependent setup times: A dynamic programming approach. Naval Research Logistics Quarterly, 21,515-524(1974)

[20] Holland, J. H.: Genetic algorithms and the optimal allocation of trials. SIAM Journal on Computing, 2 (2), 88-105(1973)

[21] Rinnooy Kan. A.: Machine Scheduling Problem: Classification, Complexity and Computation. Martinus Nijhoff,Hague, (1976)

[22] Panwalkar.S.S., Iskander.W.: A Survey of Scheduling Rules. Operations Research, 125(1), 45-62 (1977)

[23] Arabinda Tripathy.: Integer linear programming, management science, 30(12), 1473-1489 (1984)

[24] Taghi Arani, Mark kerwan, and vahid lotfi.: Integer programming on exam scheduling problem, European journal of operations research,34,372-383(1988)

[25] Holthaus, O. and Rajendran, C.: Efficient dispatching rules for scheduling in a job shop, International Journal of Production Economics, 48, 87-105 (1997)

[26]Pan, J.C.H., Fan, E.T.: Two-machine flow shop scheduling to minimize total tardiness. International Journal of Systems Science 28, 405414 (1997)

[27] Chen,H., Chu,C. and Proth,J.M..: An Improvement of the Lagrangean Relaxation Approach for Job Shop Scheduling: A Dynamic Programming Method, IEEE Transaction on Robotics and Automation..14(5), 786-795 (1998)

[28] Chryssolouris, G., Mavrikios, D., Papakostas, N., Mourtzis, D., Michalos, G., and Georgoulias, K.: Digital manufacturing: history, perspectives, and outlook. Proc. IMechE, Part B: J. Engineering Manufacture, 223(5), 451-462 (2009)

[29]Samir Barman, Joao V. Lisboa.: Cost performance of simple priority rule combinations, Journal of Manufacturing Technology Management, 21 (5), 567 - 584 (2010)

[30] Ko.H-H., Kim J., Kim .S.S., Baek. J.G.: Dispatching Rule for Non-identical Parallel Machines with Sequence-dependent Setups and Quality Restrictions, Computers \& Industrial Engineering 59, 448-457(2010)

[31] Kayvanfar V., Mahdavi I., Komaki GM.: Single machine scheduling with controllable processing 
times to minimize total tardiness and earliness. Computers \& Industrial Engineering , 65(1): 166175(2013)

[32] Kuo-Ching Ying., Chung-Cheng Lu., Jhao-Cheng Chen.: Exact algorithms for single-machine scheduling problems with a variable maintenance, Computers and Industrial Engineering, 98,427433(2016)

[33]Ling-Huey Su., Hui-Mei Wang.: Minimizing total absolute deviation of job completion times on a single machine with cleaning activities, Computers and Industrial Engineering,103 (C), 242-249 (2017)

[34] Stecke, K.E. and J.J. Solberg (1981), “Loading and Control Policies for a Flexible Manufacturing System.” International Journal of Production Research, 19 (5), 481-490.

[35]Bilge U, Ulusoy G.: A time window approach to simultaneous scheduling of machines and material handling system in an FMS. Operation Research , 43(6),1058-1070 (1995)

\section{Acknowledgments}

The authors acknowledge with thanks the financial assistance offered by DST-SERB, Govt.of India wide file. No: SB/EMEQ-501/2014 for carry out this work.

Authors: Nageswara Rao Medikondu, Mechanical Department, JNTUK, Kakinada, Andhra Pradesh 533003, India.

Narayana Rao K., Mechanical Department, Govt Polytechnic, Vijayawada, Andhra Pradesh, 520008 India

Ranga Janardhana G., Mechanical Department, JNTUA, Anantapur, Andhra Pradesh 533003, India E-mail: medikondu1979@gmail.com 